\title{
ASSESMENT OF ANTIOXIDANT AND CYTOTOXIC ACTIVIY OF ESSENTIAL OIL EXTRACTED FROM LAVANDULA ANGUSTIFOLIA \\ CALLUS LEAVES
}
S. F. Hamad
Lecture
Z. O. Salman
Lecture
B. M. J. Alwash
Prof.

Dept. of Bio., Coll. Of Sci. for Women, University of Baghdad, Baghdad, Iraq

Sumayafadhil80@gmail.com

zainab19831210@yahoo.com

bushraalwash1966@gmail.com

\section{ABSTRUCT}

This study was aimed to estimate the effect of essential oil extracted from callus of Lavandula angustifolia leaves as antioxidant and cytotoxic activity (in vitro). Different concentrations of essentail oil were selected, including $20,40,60,80$ and $100 \mu \mathrm{g} / \mathrm{ml}$ in determining antioxidant activity by using Free radical 1,1 Dyphenyl-2-picrylhydrazyl radical (DPPH). The results showed the efficacy of essentail oil as an antioxidant and the highest effect at $100 \mu \mathrm{g} / \mathrm{ml}$ reaching $97 \%$ and $87 \%$ at $80 \mu \mathrm{g} / \mathrm{ml}$ respectively. Different concentrations of essential oil ( $12.5,25,50,75$ and 100$) \mu \mathrm{g} / \mathrm{ml}$ were select to determine the effect of oil on human cervical cancer (HeLa) cancer cell line and a breast epithelial cell line (HBL) normal cell line after 72 hours from exposure time, and then antiproliferative activity of this oil was studied using MTT assay. The results showed the oil of $L$. angustifolia callus have high antioxidant influence $(97 \%)$ in $100 \mu \mathrm{g} / \mathrm{ml}$ concentration followed by $(87 \%)$ in concentration $80 \mu \mathrm{g} / \mathrm{ml}$. The inhibition effect of extract on cell proliferation in HeLa cell line at highest concentration which reached $77 \%$. The study confirmed the possibility of using essential oil from $L$. angustifolia callus could be used for medical application and treatment various types of cancer disease.

Key wards: Lavandula angustifolia, plant tissue culture, oil, cancer cell line.

\begin{tabular}{|c|c|c|}
\hline حمد وآخرون & & 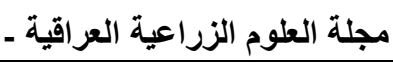 \\
\hline \multicolumn{3}{|c|}{ تقدير الفعالية المضادة للاكسدة للزيت الطيار المستخلص من كالس اورلق نبات اللافندر وتقييم فعاليته السمية } \\
\hline بشرى محمد جابر علوش & زينب عمران سلمان & 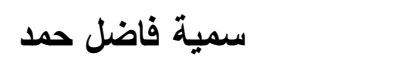 \\
\hline 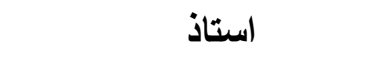 & مدرس & مدرس م \\
\hline
\end{tabular}

قسم علوم الحياة، كلية العلوم للبنات، جامعة بغداد، بغداد، العرلق.

المستخلص

هافت الدراسة الى تقدير تاثير الزيت الطيار المستخلص من كالس اولق نبات اللافندر ( Lavandula angustifolia )

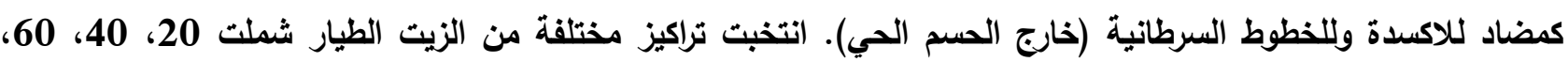
1,1 Dyphenyl-2- DPPH 100 مايكروغرام/ مللتر في تحديد الفعالية المضادة للاكسدة باستخدام مادة) picrylhydrazyl radical مايكروغرام/ مل حيث وصلت الى 97\% ثم 87\% عند التركيز 80 مايكروغرام/ مل على التوالي. كما انتخبت تراكيز من الزيت

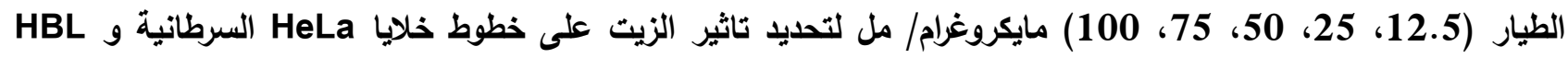

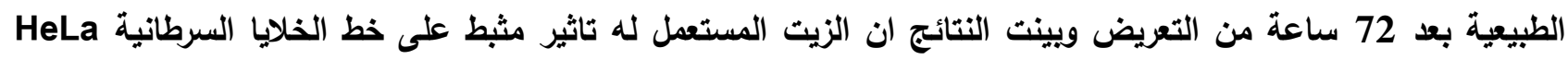
حيث اعطى اعلى فعالية سمية (77)\% عند التركيز 100 مايكروغرا/ مل. اكلت الدراسة الى امكانية استعمال الزيت الطيار المستخلص من كالس نبات اللافندر في التطبيقات الطبية وفي معالجة انواع مختلفة من السرطان. الكلمات المفتاحية: نبات اللافندر، زراعة الانسجة النباتية، الزيت، الخطوط السرطانية 


\section{INTRODUCTION}

Lavandula angustifolia, the English lavender, is plant species that native to the southern Europe and Mediterranean. It's belonged to family Lamiaceae which contain 25-30 different species $(5,16)$. Plant grows as a small shrub up to $60 \mathrm{~cm}$ high, the bottom of stem was woody while the top was green with linear leaves and blue- violet flowers arranged in circle at the top of stem $(9,15)$. Medicinal properties of lavender were known since ancient time, Romans used it as additive for bath and use oil in the middle ages in perfumes and soap. L. angustifolia was used in cosmetics, shampoo, food processing, tea and traditional medicine as sedative, antispasmodic, antidiabetic, aromatherapy and mantihypertensive against flu and colic, treat rheumatic diseases and nephrotic syndroms. In Arabic medicine it was used to treat kidney and stomach pain $(10,20,11)$. Lavandula angustifolia considered most important species due to high quality of its essential oil. The oil of its flowers and leaves are colorless or light yellow having bitter test. (8). Phytochemical studies of $L$. angustifolia revealed that the major constituents of its essential oil are 1-8cineol, camphor, linalyl acetate, lavandulol, linalool, limonene, terpenes and terpenoids. Essential oil may vary depending on growing location, climate, genotype, stage of growth plant and extraction methods (7, 19). These constituents in the oil have valuable pharmacological properties such as antioxidant, anti-inflammatory and antimicrobial (19). Some studies have shown that some constituents of lavender essential oil have anticancer and antimutagenic properties. Components of essential oil can be encapsulated in polymers as targeted drug delivery system and local administrated to prostate cancer, lung and liver cancer. Sixty percent of anticancer compounds derived from plants due to their low side effect relative to chemical drug $(6,17)$. Bozin et al (6) mentioned that aryl-benzofuran compounds isolated L. angustifolia showed significant growth inhibition of A549 (alveolar basal epithelial carcinoma), NB4 (leukemia), PC3 (prostate cancer) and MCF7 (breast adenocarcinoma) cell lines, and some constituents isolated from ethyl acetate extract of lavender show stronger anti-oxidant activity than vitamin $\mathrm{C}$. The antitumor activity essential oils related to linalyl acetate, camphor and alpha-terpineol which caused inhibition of growth of human cancer cell line. Antioxidant substances in essential oils prevent oxidative damage of cell and reactive oxygen species (ROS) reacting with free radical, scavenging free radicals. The aim of this study was to determine the antioxidant activity of essential oil extracted from $L$. angustifolia callus of leaves and evaluate the cytotoxic activity.

\section{MATERIALS AND METHODS}

The callus of L. angustifolia were collect from callus cultures which initiated from leaves of L. angustifolia growing on Murashige and Skoog (MS) medium supplemented with (10 $\mathrm{mg} / \mathrm{l}$ benzyl adenine) and $3 \mathrm{mg} / \mathrm{l}$ naphthalene acetic acid, extraction and analysis were done as mentioned in (4).

\section{Antioxidant activity}

Oil of callus was assessed by quantifying the scavenging ability to the free radical by using 1,1 Dyphenyl-2-picrylhydrazyl (DPPH). Equal volumes $(0.5 \mathrm{ml})$ of DPPH solution $(0.4 \mu \mathrm{M})$ and $1 \mathrm{ml}$ of each concentration $(20,40,60,80$ and $100 \mu \mathrm{g} / \mathrm{ml}$ ) from extract were mixed and allowed to stand for $30 \mathrm{~min}$ at room temperature in the dark. The absorbance of samples was recorded at $518 \mathrm{~nm}$, by a spectrophotometer. Ascorbic acid was used as standard. The scavenging activity was calculated according to the formula:

$$
=\frac{\begin{array}{l}
\text { Scavenging activity } \% \\
\text { A18 of control }- \text { A518 of sample }
\end{array}}{\text { A518 control }} \times 100
$$

Where A518 of control is the absorbance of DPPH prepared in methanol; A518 of sample is the absorbance of DPPH with sample of extracted oil or compound. This experimental repeated triplicate for callus extract (4).

\section{Cytotoxic activity}

Maintenance of cell culture: The cell lines used in this study were supplied by tissue culture unit/ Iraqi Centre Cancer. One cancer cell lines were used in this search (HeLa cell line). It was derived from cervical cancer cells taken on February 8, 1951 from Henrietta Lacks, a patient who died of her cancer. The (HBL) was used as normal cells. HeLa cancer cell line and HBL normal cell line were maintained in RPMI-1640 supplemented with 
$10 \%$ fetal bovine serum, 100 units/ ml penicillin, and $100 \mu \mathrm{g} / \mathrm{ml}$ streptomycin. Cells were passaged using Trypsin-EDTA reseeded at $80 \%$ confluence twice a week and incubated at $37^{\circ} \mathrm{C}(2,3)$.

\section{Cytotoxicity assays}

To determine the cytotoxic effect of essential oil, the MTT cell viability assay was done using 96-well plates. Cell lines were seeded at $1 \times 10^{4}$ cells/ well. After 24 hours or a confluent monolayer was achieved, cells were treated with tested compounds at different concentration. Cell viability was measured after 72 hours of treatment by removing the medium, adding $28 \mu \mathrm{L}$ of $2 \mathrm{mg} / \mathrm{ml}$ solution of MTT and incubating the cells for 2.5 hours at $37^{\circ} \mathrm{C}$. After removing the MTT solution, the crystals remaining in the wells is solubilized by the addition of $130 \mu \mathrm{L}$ of DMSO (Dimethyl Sulphoxide) followed by incubation at $37^{\circ} \mathrm{C}$ for 15 min with shaking. The absorbency was determined on a microplate reader at $492 \mathrm{~nm}$; the assay was performed in triplicate. The inhibition rate of cell growth (the percentage of cytotoxicity) was calculated as the following equation:

\section{Cytotoxicity $=\mathbf{A}-\mathrm{B} / \mathrm{A} * \mathbf{1 0 0}$}

Where A and B are the optical density of control and the optical density of test respecting. For visualize the shape of cells under inverted microscope, $200 \mu \mathrm{L}$ of cell suspensions were seeded in 96-well microtitration plates at density $1 \times 10^{4}$ cells $\mathrm{mL}^{-1}$ and incubated for 48 hours at $37{ }^{\circ} \mathrm{C}$. Then the medium removed and added essential oil after
24 hours, the plates were stained with $50 \mu \mathrm{L}$ with crystal violet and incubated at $37^{\circ} \mathrm{C}$ for $15 \mathrm{~min}$, the stain was washed with tap water until the dye removed. The cell observed under inverted microscope at $100 x$ magnification microscope filed and photographed with digital camera (14).

\section{Statistical analysis}

The Statistical Analysis System- SAS (2012) program was used to effect of difference factors in study parameters. Least significant difference- LSD test was used to significant compared between means in this study.

\section{RESULTS AND DISCUSSION}

\section{Antioxidant activity}

The antioxidant activity was expressed in term percentage of inhibition, the value of standard of ascorbic acid obtained and compared with antioxidant activity. The results in Table 1 show the essential oil concentrations (20-100) $\mu \mathrm{g} / \mathrm{ml}$ have response and varied of antioxidant activity from (31-97) \%. The highest activity of essential oil is a reflection of its chemical compositions. The high content of linoleic acid as mentioned by (4) was contributed to the antioxidant activity of the oil from $L$. angustifolia and can be regarded as a source of antioxidant with high value. Hamad et al Showed that extract of L. angustifolia has superior antioxidant capacity due to high content of linalool. The differences in constituents of lavender essential oil due to environmental, genetic factor and source of essential oil.

Table 1. Antioxidant activity of L. angustifolia essential oil of callus initiation from leaf explant compared with ascorbic acid

\begin{tabular}{|c|c|c|c|}
\hline \multirow{2}{*}{$\begin{array}{c}\text { Concentration } \\
\mu \mathrm{g} / \mathrm{ml}\end{array}$} & \multicolumn{2}{|c|}{ Means $\pm \mathrm{SE}$} & \multirow[t]{2}{*}{ LSD value } \\
\hline & Anti-Oxidation & $\begin{array}{l}\text { Ascorbic } \\
\text { (Control) }\end{array}$ & \\
\hline 20 & $31.39 \pm 0.95 \mathrm{e}$ & $58.60 \pm 0.63 \mathrm{c}$ & $3.887 * *$ \\
\hline 40 & $50.41 \pm 0.71 \mathrm{~d}$ & $81.69 \pm 0.92 b$ & $5.136 * *$ \\
\hline 60 & $79.33 \pm 1.09 c$ & $84.60 \pm 0.78 b$ & $2.809 * *$ \\
\hline 80 & $87.71 \pm 1.21 b$ & $97.20 \pm 1.04 a$ & $3.061 * *$ \\
\hline 100 & $97.85 \pm 0.49 a$ & $98.60 \pm 1.37 \mathrm{a}$ & 2.677 NS \\
\hline LSD value & $2.931 * *$ & $4.027 * *$ & --- \\
\hline $\begin{array}{l}\text { Means having } \\
\text { significantly, ** }\end{array}$ & $\begin{array}{l}\text { the different } \\
\text { 01). }\end{array}$ & etters in same co & lumn differed \\
\hline
\end{tabular}

\section{Cytotoxic activity}

The cytotoxic activity was determined by using five different concentrations of $L$. angustifolia essential oil on one cancer cell line and one normal cell line after 72 hours exposure time. The results show significant inhibition of cell proliferation in HeLa cell line after 72 hours. The cell proliferation was significantly lower when compared to untreated control cell. After 72 hours of 
treatment these cells with $L$. angustifolia essential oil at concentrations $12.5,25,50,75$ and $100 \mu \mathrm{g} / \mathrm{ml}$, the cytotoxicity of essential oil showed good cytotoxic effect. The results indicate that $L$. angustifolia essential oil is considered to be particularly valuable source of anti-proliferative and cytotoxic substances. Apoptogenic property was investigated through morphological changes Hela cell line using inverted phase contrast microscope. As seen in Figure 1, the control (untreated) showed that cells maintained their original morphology form that most of the control cells adherent to the tissue culture dishes. In contrast, Hela cells treated with L. angustefolia essential oil exhibit high efficiency on proliferation and morphology. A

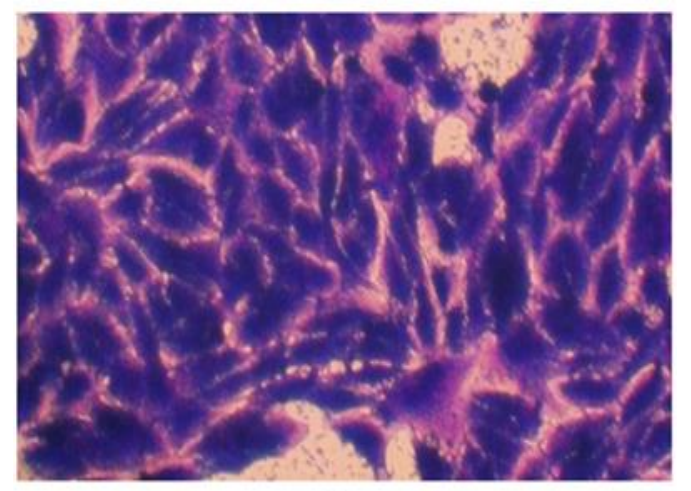

B

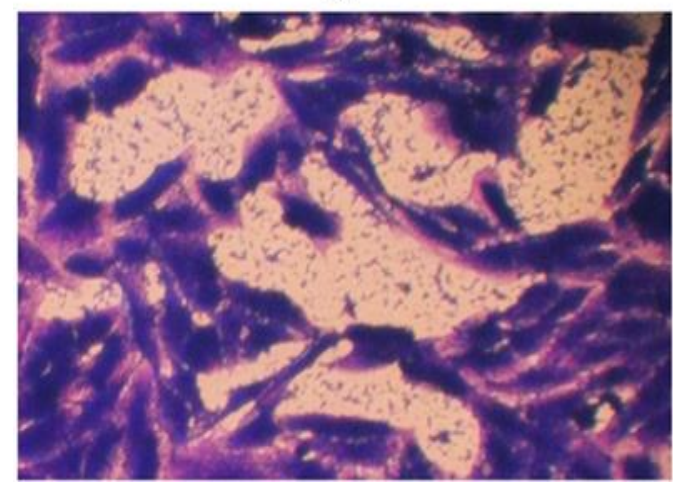

Figure1. Antiproliferative activity of $L$. angustifolia essential oil of callus initiated from leaf explant against HeLa cells (A: untreated cell (control), B treated cell

Figure 2 revealed that essential oil inhibit cell growth at highest concentration which reached $77 \%$ while reduced at lower concentration gave $8 \%$.

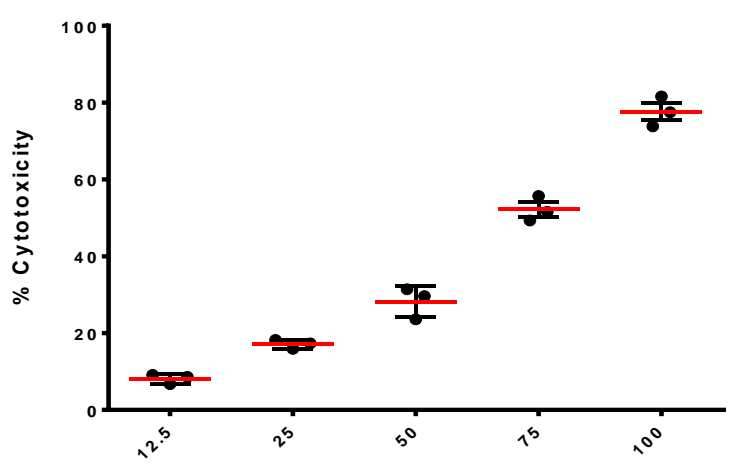

Figure 2. Cytotoxicity of L. angustifolia essential oil of callus initiated from leaf explant against HeLa cells

These concentrations were not significant on HBL cell line, or in another meaning the essential oil has no effect on normal cell (Figure 3).

A

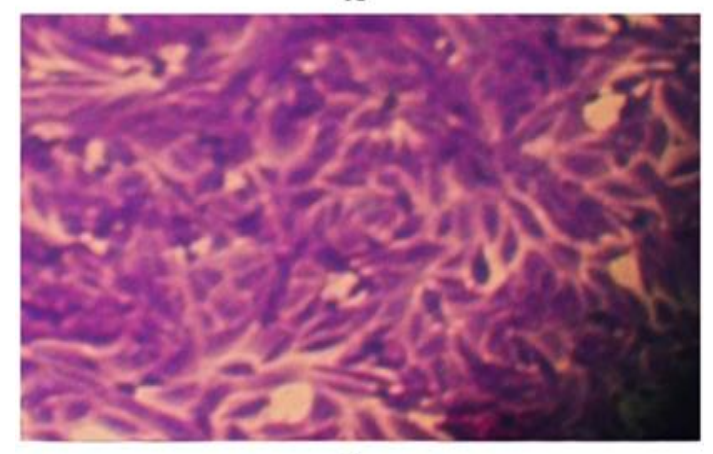

B

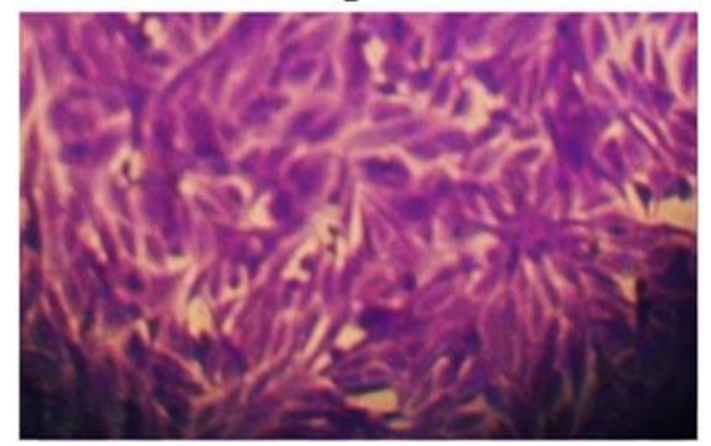

Figure 3. Antiproliferative activity of $L$. angustifolia essential oil of callus initiated from leaf explant against HBL cells (A: untreated cell (control), B treated cell

This study was indicated that components present in L. angustifolia essential oil associated with molecular mechanisms. The mixture of these compounds induced apoptosis and inhibited cell proliferation in Hela cells. It has been shown that more components in this oil have anticancer properties. Natural products play important role in drug discovery and studied these compounds have led to development many potent anticancer agents. Plant essential oils became the focus of 
phytomedicine researcher, L. angustifolia essential oil display some variation (1). Zhao et al (21) investigated that linalool and linalyl acetate are the major constituents in $L$, angustifolia essential oil have therapeutic effect on human prostate cancer cells. Results agree with many researchers who mentioned that essential oil of $L$. angustifolia exhibited remarkable anticancer and antiproliferative activity against cancer cells, it observed that cell growth and viability in cancer cell line were inhibited (12).

\section{REFERENCES}

1. Abou-Baker, D.H. 2020 Achilliea millefolium L. ethyle acetate fraction induces apoptosis and cell cycle arrest in human cervical cancer (HeLa) cells. Annals of Agricultural Science. 65(1): 42-48

2. Ali, Z., A. J.and. A.Al-Shammari 2019. A Gold nanoparticles inhibiting proliferation of human breast cancer cell line. Research Journal of Biotechnology. 2019; 14: 79-82

3. Alsaedi, I.I.J, Taqi, A. M. and G.M. AbdulHussein. Sulaiman and M.S. Jabir 2019. Graphene nanoparticles induces apoptosis in MCF-7 cells through mitochondrial damage and NF-KB pathway. Material Research Express.6(9).

4. Alwash, B.M.J., Z.O. Salman and S.F. Hamad 2020. Qualitative and quantitative of active constituents in callus of Lavendula angustifolia plant in vitro. Baghdad Science Journal. 17(2): 591-598

5. Bona, C.M., V. Reinhart, L.A. Biasi and F. Zanette.2011 Lavandula denata and Lavandula angustifolia in vitro organogenesis. Plant Cell Cult. Micropropag, 7(2): 66-70

6. Bozin, B. N. Mimica-Dukic, N. Simin and G. Anackov. 2006. Characterization of the volatile composition of essential oils of some Lamiaceae spices and the antimicrobial and antioxidant activities of the entire oils. J Agric Food Chem. 54(5).

7. Caputo, L., L.F. Souza, S. Alloisio, L. Cornara and V.L. Feo. 2016. Coriandrum sativum and Lavandula angustifolia essential oils: chemical composition and activity on central nervous system. International Journal of Molecular Sciences. 17:2-12.

8. Cardia, G.F.E., S.E. Silva, E.L. Silva, N.S.Uchida, H.A.O. Cavalcante, L,L, Cassaritti, V.E.C. Salvadego, R.A. Spirollino,
C.A. Beracine-Amado and R.K.N. Cuman.2018. Effect of lavender ( Lavandula angustifolia) essential oil an acute inflammatoryn response. Evidence-based Complementary and Alternative Medicine.110.

9. Danila E, D.A. Kaya, M. Patrascu, M. Albukaya, and S. Kumbakisaka.2018. Comparative study of Lavandula angustifolia essential oils obtained by microwave and classical hydrodistillation. REV.CHIM. 96(8): 2240-2244

10. Ez zoubi, Y., D. Bousta and A. Farah. 2020. A phytopharmalogical review of mediterrnean plant: Lavandula stoechas L. Clinical Phytoscience. 6(9):2-9

11. Georgia-Eirini, D., K. Christos, H. Dimitra and L. Diamanto. 2018. Antioxidant contribution of Lavender ( Lavandula angustifolia), Sage ( Salvia officinalis), Tilia (Tilia tomentosa) and Sideritis ( Sideritis perfoliata) beverages prepared at home.SDRP Journal of Food Science and Technology. vol 3 (4): 360-377

12. Gezici S.2018. Promising anticancer activity of lavender (Lavandula angustifolia Mill) essential oil through induction both apoptosis and necrosis. Annals of Phytomedicine. 7(2): 38-45.

13. Hamad, K.J., S.J.K.Al-Shaheen, R.A. Kaskoos, J. Ahmad, M. Jameel and S.R. Mir. 2013.Essential oil composition and antioxidant capacity of Lavandula angustifolia from Iraq. International Research Journal of Pharmacy. 2013; 4(4): 117-120

14. Kadhem, H.A., S.A.Ibraheem, M.S. Jabir, A.A. Kadhim and Z.J. Taqi. 2019. Florin MD. Zinc oxide nanoparticles induces apoptosis in human breast cancer cells via caspase- 8 and p53 pathway. Nano Biomed.11(1):35-43

15. Khalajee, M. B. K. Jaimand, S. Mozaffari and S.A. Mirshokraie.2017. Comparative study on essential oil of Lavandula officinalis L. from three different sites with different methods of distillation. Journal of Medicinal Plant and By- Products. 2017; 1:53-58

16. Martin, R.P., R.A.S. Gomes, A.C.G. Malpass and M. H. Okura.2019. Chemical characterization of Lavandula denata $\mathrm{L}$. essential oil grown in Uberaba- MG.CR, Santa Maria. 49 (8). 
17. Niksic, H., E. Kova-Besovicl, E. Rosmarinus officinalis, Thymus vulgaris L. Makarevic, K., Duric, J. Kusturica, and S. and Lavender x intermedia. Archives of Breast Muratovic.2017. Antiproliferative, Cancer. 5(2): 81-89.

antimicrobial, and antioxidant activity of 20. Yusufo, A., L.K.Celik and G. Lar. 2004. Lavandula angustifolia Mill. Essential oil. Journal of Health Sciences. 7(1): 35-43

18. SAS. 2012. Statistical analysis System. Users Guide. Statistical. Version 9.1th ed. SAS. Inst. Inc. Cary. N.C. USA Utilization of Lavandula angustifolia Miller extracts as natural repellents, pharmaceutical and industrial auxiliaries. J. Serb.Chem. Soc.69 (1): 1-7

19. Tabtabaeia, S.M., F. Kianinadh, M. Nasiria, N. Tightiza, M. Asadipoura and M. Gohari. 2018. In vitro inhibition of MCF-7 human breast cancer cells by essential oils of 21. Zhao Y, R, Chen. Y Wang, Qing Chen, W, Wang. Y, Yang .2017. In vitro and in vivo efficancy studies of Lavender angustifolia essential oil and its active constituents on the proliferation of human prostate cancer. Integrative Cancer Therapies. 16(2): 215-226. 